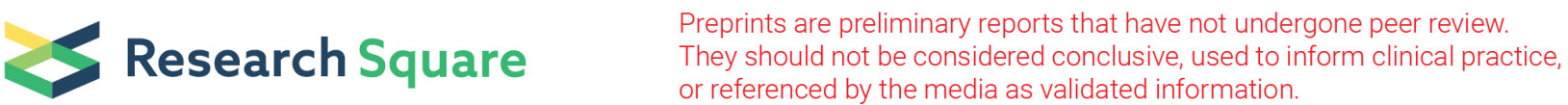 \\ Genetic Diversity of Groundnut (Arachis hypogaea L.) Accessions using Inter Simple Sequence Repeats (ISSRs) Marker
}

\section{Mohammed Abdela}

Axum University

Mulugeta Kebede ( $\nabla$ mulugeta.kebede@astu.edu.et)

School of Applied Natural Sciences, Adama Science and Technology University https://orcid.org/00000002-9185-9325

Tiliye Feyissa

Addis Ababa University

\section{Research}

Keywords: Arachis hypogaea, Genetic diversity, ISSR Marker, Polymorphism, Nei's gene diversity

Posted Date: December 11th, 2020

DOl: https://doi.org/10.21203/rs.3.rs-125057/v1

License: (1) (7) This work is licensed under a Creative Commons Attribution 4.0 International License. Read Full License 


\section{Abstract}

Background: Groundnut (Arachis hypogaea L.) belongs to the family Leguminoseae. It is the world's most important source of edible oil and vegetable protein. To our knowledge, little is known about the genetic variability of cultivated Ethiopian A. hypogaea at a molecular level. It is important to understand the genetic diversity of the crop to collect, conserve and use the germplasm for variety development. In the present study, ISSR markers were used to determine the genetic variability and diversity of 43 accessions of $A$. hypogaea collected from different regions of Ethiopia.

Results: Four ISSR primers were used to generate 56 reproducible bands of which 29 (51.8\%) were polymorphic. The band size ranges from $120 \mathrm{bp}$ to $1100 \mathrm{bp}$. The number of amplified bands varied from 12 in primer UBC841 to 18 in primer UBC 881. The polymorphic bands percentage ranges from $27.8 \%$ of Primer UBC 881 to $84.6 \%$ of primer UBC 857 . The polymorphic information content (PIC) value ranges from 0.29 to 0.76 with the average value 0.49 . The mean Nei's gene diversity and Shannon's information index were 0.25 and 0.33 , respectively. Genetic relationship between A. hypogaea accessions based on Jaccard's pair wise similarity coefficients varies from $44 \%$ to $83 \%$ with an average value of $63.5 \%$. The UPGMA dendrogram based on cluster analysis grouped A. hypogaea accessions into five distinct clusters at $63.5 \%$ similarity coefficient, and the principal coordinate analysis revealed similar grouping.

Conclusions: Even though in both UPGMA and PCoA most of the accessions were grouped in separate clusters irrespective of their geographic origins, the ISSR marker-based analysis shows the presence of genetic variability among the accessions. Moreover, the current study demonstrated the potential informativeness of ISSR markers in estimating the extent of genetic variation in A. hypogaea accessions.

\section{Introduction}

Groundnut or peanut (Arachis hypogaea L.) belongs to the family Leguminoseae and genus Arachis. Cultivated groundnut (Arachis hypogea L.) is a highly self-pollinated, allotetraploid annual legume with $2 \mathrm{n}$ $=4 \mathrm{x}=40$ with a basic chromosome number of $\mathrm{x}=10$ [1]. A. hypogaea is cultivated and grown throughout the tropics and sub-tropics between $40^{\circ}$ south and $40^{\circ}$ north of the equator where the annual rainfall ranges between 500 to $1200 \mathrm{~mm}$ and with average daily temperature of higher than $20^{\circ} \mathrm{C}$ [2]. Major A. hypogaea growing countries include China, India, the United States and Nigeria [3].

A. hypogaea is the world's 4th most important source of edible oil and 3rd most important source of vegetable protein [4]. A. hypogaea seeds contain $42-50 \%$ oil, $26 \%$ protein, $18 \%$ carbohydrates, and are also rich source of riboflavin, thiamine, nicotinic acid and vitamin E [5]. A. hypogaea is one of the four economically important oilseed crops along with noug, flax and sesame in Ethiopia [2]. Besides, this crop helps small scale producers in getting significant revenue and also helps Ethiopia in getting foreign currency earnings through export. Being a legume, this plant improves soil by fixing nitrogen biologically without consuming non-renewable energies and without disturbing agro-ecological balance [6].

In Ethiopia, A. hypogaea is grown and covered nearly 80,000 hectares [7] of arable land per annum and the major producing regions are Eastern Hararghe in Oromia and Metekel in Benishangul-Gumuz regional state 
$[7,8]$. Despite its importance, the national average yield produced by the farmers in Ethiopia is considerably low, 1.3 tons/ha, indicating the need of maximum effort to improve productivity [9].

Genomic research can provide new tools and resources to revolutionize crop genetic improvement and production. It also provides accurate knowledge at molecular level which is not possible with phenotypic markers [10]. Assessment of genetic diversity is an important step in any crop improvement program [11]. Understanding the molecular basis of the essential biological phenomena in plants is crucial for the effective conservation, management, and efficient utilization of plant genetic resources (PGR) [12]. Collecting DNA marker data to determine whether phenotypically similar cultivars are genetically similar would therefore be of great interest in crop breeding programs [13]. Evaluation of genetic diversity could be based on morphological or molecular markers. Morphological features may not be efficient as they are highly influenced by environments. Molecular marker technique is an efficient tool for genetic variation evaluation in plants [14].Consequently, the development of marker protocols such as RFLP, AFLP, ISSR, SNP and SSR have revolutionized the genetic analysis by detecting level of polymorphism [15].

Inter Simple Sequence Repeats (ISSR) marker has been reported as a rapid, reproducible, and cheap fingerprinting technique based on the variation found in the regions between microsatellites [21, 22]. The ISSR method has several benefits over other techniques: first, it is known to be able to discriminate between closely related genotypes and second, it can detect polymorphisms without any previous knowledge of the crop's DNA sequence [23]. In addition, it does not require genome sequence information; it leads to multilocus, highly polymorphous patterns and produces dominant markers [24]. ISSR PCR is a fast, inexpensive genotyping technique based on variation in the regions between microsatellites [23]. ISSRs segregate mostly as dominant markers following simple Mendelian inheritance. ISSR analyses offer breeders and geneticists with competent means to link phenotypic and genotypic variations in various fields of plant improvement [25].

Genetic diversity study in A. hypogaea, based on morphological, biochemical and some molecular markers has been reported [16-20]. However, more molecular marker-based genetic diversity study of $A$. hypogaea accessions in Ethiopia is demanding. In this paper we report the level and pattern of genetic variability in 43 accessions of $A$. hypogaea grown in different regions of Ethiopia using ISSR markers. Moreover, we addressed the potential informativeness of ISSR markers for identifying A. hypogaea accessions.

\section{Material And Methods}

\section{Plant Materials}

Seeds of 43 A. hypogea accessions collected from different regions of Ethiopia were obtained from Ethiopian Biodiversity Institute (EBI), Addis Ababa, Ethiopia. The accessions were collected from different geographical locations of Ethiopia (Fig. 1). The seeds of all the 43 A. hypogaea accessions were planted in plastic pots containing sandy loamy (composted) soil and maintained in a greenhouse under controlled temperature $\left(30^{\circ} \mathrm{C}\right)$ for about four weeks at Awash Melkasa Agricultural Research Center. Watering was done once a day regularly. Fresh young leaves from four week old plants were collected from plants of each 
accession in tubes containing silica gel for genomic DNA extraction. These accessions, their gene bank number, code, collection region, locality and geographical location (latitude and longitude) are listed in Table 1. 
Table 1

List of accessions included in the present study: Gene bank accession number, the corresponding code, collection region and sites along with their latitude and longitude

\begin{tabular}{|c|c|c|c|c|c|c|}
\hline $\begin{array}{l}\text { S. } \\
\text { No. }\end{array}$ & $\begin{array}{l}\text { Gene } \\
\text { bank } \\
\text { accession } \\
\text { no }\end{array}$ & Code & Collection region & locality & Latitude $(\mathrm{N})$ & $\begin{array}{l}\text { Longitude } \\
\text { (E) }\end{array}$ \\
\hline 1 & 19739 & GOB 1 & Oromia/Misrak/Babile & Berkele/s 1 & $9^{\circ} 12^{\prime} 25.33^{\prime \prime}$ & $42^{\circ} 21^{\prime} 26.31^{\prime \prime}$ \\
\hline 2 & 19740 & GOB 2 & Oromia/Misrak/Babile & Berkele/s 2 & $9^{\circ} 12^{\prime} 25.35^{\prime \prime}$ & $42^{\circ} 21^{\prime} 27.34^{\prime \prime}$ \\
\hline 3 & 19741 & GOB 3 & Oromia/Misrak/Babile & $\begin{array}{l}\text { Babile/Shek } \\
\text { A. }\end{array}$ & $9^{\circ} 11^{\prime} 54.45^{\prime \prime}$ & $42^{\circ} 21^{\prime} 41.22^{\prime \prime}$ \\
\hline 4 & 19742 & GOB 4 & Oromia/Misrak/Babile & Awsherit 1 & $9^{\circ} 09^{\prime} 21.23^{\prime \prime}$ & $42^{\circ} 22^{\prime} 21.34^{\prime \prime}$ \\
\hline 5 & 19743 & GOB 5 & Oromia/Misrak/Babile & Awsherit 2 & $9^{\circ} 09^{\prime} 21.29^{\prime \prime}$ & $42^{\circ} 22^{\prime} 21.28^{\prime \prime}$ \\
\hline 6 & 19744 & GOB 6 & Oromia/Misrak/Babile & Lecole & $9^{\circ} 07^{\prime} 36.32^{\prime \prime}$ & $42^{\circ} 21^{\prime} 02.33^{\prime \prime}$ \\
\hline 7 & 19745 & GOB 7 & Oromia/Misrak/Babile & Ifa Gende 1 & $9^{\circ} 13^{\prime} 42.11^{\prime \prime}$ & $42^{\circ} 18^{\prime} 22.18^{\prime \prime}$ \\
\hline 8 & 19746 & GOB 8 & Oromia/Misrak/Babile & Ifa Gende 2 & $9^{\circ} 13^{\prime} 41.11^{\prime \prime}$ & $42^{\circ} 18^{\prime} 22.28^{\prime \prime}$ \\
\hline 9 & 19747 & GOB 9 & Oromia/Misrak/Babile & Ifa Gende 3 & $9^{\circ} 15^{\prime} 30.21^{\prime \prime}$ & $42^{0} 18^{\prime} 21.12^{\prime \prime}$ \\
\hline 10 & 19748 & $\begin{array}{l}\text { GOB } \\
10\end{array}$ & Oromia/Misrak/Babile & Medigana 1 & $9^{\circ} 16^{\prime} 06.13^{\prime \prime}$ & $42^{\circ} 18^{\prime} 12.43^{\prime \prime}$ \\
\hline 11 & 19749 & $\begin{array}{l}\text { GOB } \\
11\end{array}$ & Oromia/Misrak/Babile & Medigana 2 & $9^{\circ} 16^{\prime} 06.21^{\prime \prime}$ & $42^{\circ} 18^{\prime} 24.28^{\prime \prime}$ \\
\hline 12 & 19750 & $\begin{array}{l}\text { GOB } \\
12\end{array}$ & Oromia/Misrak/Babile & Dendaro & $9^{\circ} 17^{\prime} 25.21^{\prime \prime}$ & $42^{\circ} 17^{\prime} 25.14^{\prime \prime}$ \\
\hline 13 & 19751 & $\begin{array}{l}\text { GOB } \\
13\end{array}$ & Oromia/Misrak/Babile & Tofic 1 & $9^{\circ} 16^{\prime} 06.36^{\prime \prime}$ & $42^{\circ} 17^{\prime} 36.25^{\prime \prime}$ \\
\hline 14 & 19752 & $\begin{array}{l}\text { GOB } \\
14\end{array}$ & Oromia/Misrak/Babile & Tofic 2 & $9^{\circ} 16^{\prime} 06.41^{\prime \prime}$ & $42^{0} 17^{\prime} 36.32^{\prime \prime}$ \\
\hline 15 & 19753 & $\begin{array}{l}\text { GOB } \\
15\end{array}$ & Oromia/Misrak/Babile & Berkele & $9^{\circ} 10^{\prime} 48.27^{\prime \prime}$ & $42^{\circ} 18^{\prime} 23.12^{\prime \prime}$ \\
\hline 16 & 19754 & $\begin{array}{l}\text { GOB } \\
16\end{array}$ & Oromia/Misrak/Babile & Gende & $9^{\circ} 09^{\prime} 37.42^{\prime \prime}$ & $42^{\circ} 18^{\prime} 50.10^{\prime \prime}$ \\
\hline 17 & 19755 & $\begin{array}{l}\text { GOB } \\
17\end{array}$ & Oromia/Misrak/Babile & Gemechu & $9^{\circ} 07^{\prime} 25.34^{\prime \prime}$ & $42^{\circ} 18^{\prime} 54.03^{\prime \prime}$ \\
\hline 18 & 19756 & $\begin{array}{l}\text { GOB } \\
18\end{array}$ & Oromia/Misrak/Babile & Tula & $9^{\circ} 13^{\prime} 05.11^{\prime \prime}$ & $42^{\circ} 19^{\prime} 28.32^{\prime \prime}$ \\
\hline
\end{tabular}

Key: GOG - Oromia/Gursum, GOB - Oromia/Babile, GOBG - Oromia/Bale-Ginir, GSJ - Somalia/Jigjiga, GAW - Amhara/Wangua 


\begin{tabular}{|c|c|c|c|c|c|c|}
\hline $\begin{array}{l}\text { S. } \\
\text { No. }\end{array}$ & $\begin{array}{l}\text { Gene } \\
\text { bank } \\
\text { accession } \\
\text { no }\end{array}$ & Code & Collection region & locality & Latitude $(\mathrm{N})$ & $\begin{array}{l}\text { Longitude } \\
\text { (E) }\end{array}$ \\
\hline 19 & 19757 & $\begin{array}{l}\text { GOB } \\
19\end{array}$ & Oromia/Misrak/Babile & Tula About & $9^{\circ} 12^{\prime} 17.23^{\prime \prime}$ & $42^{\circ} 19^{\prime} 38.42^{\prime \prime}$ \\
\hline 20 & 19758 & $\begin{array}{l}\text { GOB } \\
20\end{array}$ & Oromia/Misrak/Babile & Abdul 1 & $9^{\circ} 11^{\prime} 49.22^{\prime \prime}$ & $42^{\circ} 19^{\prime} 43.37^{\prime \prime}$ \\
\hline 21 & 19759 & $\begin{array}{l}\text { GOB } \\
21\end{array}$ & Oromia/Misrak/Babile & Abdul 2 & $9^{\circ} 11^{\prime} 49.28^{\prime \prime}$ & $42^{\circ} 19^{\prime} 58.23^{\prime \prime}$ \\
\hline 22 & 19760 & GOG 1 & Oromia/Misrak/Gursum & Llalemi 1 & $9^{\circ} 19^{\prime} 33.14^{\prime \prime}$ & $42^{\circ} 26^{\prime} 05.26^{\prime \prime}$ \\
\hline 23 & 19761 & GOG 2 & Oromia/Misrak/Gursum & Llalemi 2 & $9^{\circ} 19^{\prime} 33.38^{\prime \prime}$ & $42^{\circ} 26^{\prime} 05.38^{\prime \prime}$ \\
\hline 24 & 19762 & GOG 3 & Oromia/Misrak/Gursum & Awdal & $9^{\circ} 18^{\prime} 19.23^{\prime \prime}$ & $42^{\circ} 26^{\prime} 11.36^{\prime \prime}$ \\
\hline 25 & 19763 & GOG 4 & Oromia/Misrak/Gursum & Oda 1 & $9^{\circ} 19^{\prime} 14.11^{\prime \prime}$ & $42^{\circ} 27^{\prime} 06.18^{\prime \prime}$ \\
\hline 26 & 19764 & GOG 5 & Oromia/Misrak/Gursum & Oda 2 & $9^{\circ} 18^{\prime} 37.42^{\prime \prime}$ & $42^{\circ} 28^{\prime} 38.21^{\prime \prime}$ \\
\hline 27 & 19765 & GOG 6 & Oromia/Misrak/Gursum & Oda 3 & $9^{\circ} 18^{\prime} 40.13^{\prime \prime}$ & $42^{\circ} 28^{\prime} 38.16^{\prime \prime}$ \\
\hline 28 & 19766 & GOG 7 & Oromia/Misrak/Gursum & Oda 4 & $9^{\circ} 18^{\prime} 30.32^{\prime \prime}$ & $42^{\circ} 29^{\prime} 41.38^{\prime \prime}$ \\
\hline 29 & 19767 & GOG 8 & Oromia/Misrak/Gursum & Oda 5 & $9^{\circ} 18^{\prime} 30.28^{\prime \prime}$ & $42^{\circ} 29^{\prime} 41.25^{\prime \prime}$ \\
\hline 30 & 19768 & GOG 9 & Oromia/Misrak/Gursum & $\begin{array}{l}\text { Nur Selam } \\
1\end{array}$ & $9^{\circ} 19^{\prime} 30.26$ & $42^{\circ} 28^{\prime} 38.32^{\prime \prime}$ \\
\hline 31 & 19769 & $\begin{array}{l}\text { GOG } \\
10\end{array}$ & Oromia/Misrak/Gursum & $\begin{array}{l}\text { Nur Selam } \\
2\end{array}$ & $9^{\circ} 19^{\prime} 30.53^{\prime \prime}$ & $42^{\circ} 28^{\prime} 38.45^{\prime \prime}$ \\
\hline 32 & 19770 & $\begin{array}{l}\text { GOG } \\
11\end{array}$ & Oromia/Misrak/Gursum & Odaa 1 & $9^{\circ} 21^{\prime} 54.13^{\prime \prime}$ & $42^{\circ} 29^{\prime} 50.34^{\prime \prime}$ \\
\hline 33 & 19771 & $\begin{array}{l}\text { GOG } \\
12\end{array}$ & Oromia/Misrak/Gursum & Odaa 2 & $9^{\circ} 21^{\prime} 54.24^{\prime \prime}$ & $42^{\circ} 29^{\prime} 50.46^{\prime \prime}$ \\
\hline 34 & 19772 & $\begin{array}{l}\text { GOG } \\
13\end{array}$ & Oromia/Misrak/Gursum & Abader & $9^{\circ} 17^{\prime} 51.28^{\prime \prime}$ & $42^{\circ} 24^{\prime} 14.33^{\prime \prime}$ \\
\hline 35 & 19773 & $\begin{array}{l}\text { GOG } \\
14\end{array}$ & Oromia/Misrak/Gursum & Harobata 1 & $9^{0} 17^{\prime} 12.43^{\prime \prime}$ & $42^{\circ} 23^{\prime} 43.24^{\prime \prime}$ \\
\hline 36 & 19774 & $\begin{array}{l}\text { GOG } \\
15\end{array}$ & Oromia/Misrak/Gursum & Harobata 2 & $9^{\circ} 17^{\prime} 12.38^{\prime \prime}$ & $42^{\circ} 23^{\prime} 43.28^{\prime \prime}$ \\
\hline 37 & 19775 & $\begin{array}{l}\text { GOG } \\
16\end{array}$ & Oromia/Misrak/Gursum & Harobata 3 & $9^{\circ} 16^{\prime} 12.18^{\prime \prime}$ & $42^{\circ} 23^{\prime} 18.21^{\prime \prime}$ \\
\hline
\end{tabular}

Key: GOG - Oromia/Gursum, GOB - Oromia/Babile, GOBG - Oromia/Bale-Ginir, GSJ - Somalia/Jigjiga, GAW - Amhara/Wangua 


\begin{tabular}{|c|c|c|c|c|c|c|}
\hline $\begin{array}{l}\text { S. } \\
\text { No. }\end{array}$ & $\begin{array}{l}\text { Gene } \\
\text { bank } \\
\text { accession } \\
\text { no }\end{array}$ & Code & Collection region & locality & Latitude $(\mathrm{N})$ & $\begin{array}{l}\text { Longitude } \\
\text { (E) }\end{array}$ \\
\hline 38 & 19776 & $\begin{array}{l}\text { GOG } \\
17\end{array}$ & Oromia/Misrak/Gursum & Harobata 4 & $9^{\circ} 16^{\prime} 22.20^{\prime \prime}$ & $42^{\circ} 23^{\prime} 35.12^{\prime \prime}$ \\
\hline 39 & 19777 & $\begin{array}{l}\text { GOG } \\
18\end{array}$ & Oromia/Misrak/Gursum & Awdal 1 & $9^{\circ} 17^{\prime} 20.56^{\prime \prime}$ & $42^{\circ} 26^{\prime} 26.65^{\prime \prime}$ \\
\hline 40 & 19778 & $\begin{array}{l}\text { GOG } \\
19\end{array}$ & Oromia/Misrak/Gursum & Awdal 2 & $9^{\circ} 17^{\prime} 20.48^{\prime \prime}$ & $42^{\circ} 26^{\prime} 26.51^{\prime \prime}$ \\
\hline 41 & 19779 & $\begin{array}{l}\text { GSJ - } \\
1\end{array}$ & Somalia/Jigjiga & Beledka & $9^{\circ} 17^{\prime} 51.23^{\prime \prime}$ & $42^{\circ} 39^{\prime} 08.34^{\prime \prime}$ \\
\hline 42 & 24208 & $\begin{array}{l}\text { GAW - } \\
1\end{array}$ & Amhara/Adoawe & Wangua & $10^{\circ} 48^{\prime} 45.43^{\prime \prime}$ & $36^{\circ} 25^{\prime} 35.12^{\prime \prime}$ \\
\hline 43 & 28662 & GOBG1 & Oromia/Bale & Ginir & $7^{0} 11^{\prime} 86.21^{\prime \prime}$ & $40^{\circ} 37^{\prime} 46.21^{\prime \prime}$ \\
\hline
\end{tabular}

\section{DNA Extraction}

DNA extraction and analysis were carried at Plant Molecular Genetics Research Laboratory, Department of Microbial, Cellular and Molecular Biology Department, Addis Ababa University. About $50 \mathrm{mg}$ of silica gel dried leaves for each accession were ground with mix and miller machine. Genomic DNA extraction was done based on the CTAB method [26] with minor modification in the amount of CTAB solution used $(1000 \mu \mathrm{l})$, as well as incubation and centrifugation time, to get optimal amounts of DNA. The yield of DNA isolated was measured/quantified using a Nano Drop ND-8000 UV spectrophotometer. Moreover, the purity of DNA was visually determined by agarose gel electrophoresis by running the samples on $1 \%$ agarose gel (Fig. 2). The samples were stored at $4{ }^{\circ} \mathrm{C}$ until subsequent analysis is carried out.

\section{Primer Selection and Optimization}

For PCR optimization and screening of primers, the concentration of extracted DNA from each accession were adjusted to $50 \mathrm{ng} / \mu \mathrm{l}$. A total of nine ISSR primers obtained from the Genetic Research Laboratory (Primer kit UBC), originally bought from University of British Columbia, were used for the initial testing of polymorphism and reproducibility. All the 9 primers were screened for reproducibility and polymorphism. Finally, three di-nucleotide primers (UBC810, UBC841 and UBC857), and one penta-nucleotide primer (UBC881) which shows polymorphic and reproducible bands were selected for ISSR amplification (Table 2). 
Table 2

ISSR primers screened for polymorphism and the reproducibility of the amplified bands

\begin{tabular}{|llll|}
\hline Primer & Annealing $\mathrm{T}^{\circ}\left({ }^{\circ} \mathrm{C}\right)$ & $\begin{array}{l}\text { Sequence of } \\
\text { nucleotides }\left(\mathbf{5}^{\prime} \mathbf{- 3}^{\prime}\right)\end{array}$ & Amplification pattern \\
\hline UBC810 & 45 & GAGAGAGAGAGAGAGAT & Polymorphic, Reproducible \\
\hline UBC812 & 45 & GAGAGAGAGAGAGAGAA & Not amplified \\
\hline UBC824 & 48 & TCTCTCTCTCTCTCTCG & Not reproducible \\
\hline UBC840 & 45 & GAGAGAGAGAGAGAGAYT & Not amplified \\
\hline UBC841 & 48 & GAGAGAGAGAGAGAGAYC & Polymorphic, Reproducible \\
\hline UBC842 & 45 & GAGAGAGAGAGAGAGAYG & Not amplified \\
\hline UBC848 & 45 & CACACACACACACACARC & Not reproducible \\
\hline UBC857 & 48 & ACACACACACACACACYG & Polymorphic, Reproducible \\
\hline UBC881 & 48 & GGGGTGGGGTGGGGTG & Polymorphic, Reproducible \\
\hline Source: Primer kit 900 (UBC 900); Y = Pyrimidines (C or T), R = Purines (A or G). \\
\hline
\end{tabular}

ISSR Amplification

The ISSR amplification was done using Biometra 2000 T3 Thermo-cycler. PCR amplification was carried out in a $25 \mu \mathrm{l}$ total reaction mixture containing $50 \mathrm{ng} / \mu \mathrm{l}$ template DNA, $17.5 \mu \mathrm{lddH} 20,0.5 \mu \mathrm{dNTP}$ (1.25 mM), $2.5 \mu \mathrm{l}$ PCR buffer (10xThermopol reaction buffer), $2.5 \mu \mathrm{IgCl}_{2}(2 \mathrm{mM}), 0.5 \mu \mathrm{l} \mathrm{primer} \mathrm{(20} \mathrm{pmol/}$ $\mu \mathrm{l})$ and $0.5 \mu \mathrm{l} \mathrm{Taq} \mathrm{Polymerase}(5 \mathrm{U} / \mu \mathrm{l})$. The amplification program was 4 min preheating and initial denaturation at $94{ }^{\circ} \mathrm{C}$, then 39 cycles at $94^{\circ} \mathrm{C}$ for $30 \mathrm{sec}, 1 \mathrm{~min}$ primer annealing at $45 / 48^{\circ} \mathrm{C}$ based on primers used, $90 \mathrm{sec}$ extension at $72{ }^{\circ} \mathrm{C}$ with a final extension of $7 \mathrm{~min}$ at $72{ }^{\circ} \mathrm{C}$. The PCR products were also stored at $4{ }^{\circ} \mathrm{C}$ until loaded on gel for electrophoresis.

\section{Electrophoresis}

Agarose gel (1.67\%) was prepared using $300 \mathrm{ml}$ TBE mixed with $5.01 \mathrm{~g}$ agarose using $500 \mathrm{ml}$ Erlenmeyer flask and then boiled in micro oven for 3 minutes. After it was cooled for about $20 \mathrm{~min}$ at room temperature, $12 \mu \mathrm{l}$ Ethidium Bromide $(10 \mathrm{mg} / \mathrm{ml})$ was added and the gel was poured on gel casting tray to solidify.

The amplified products were run on to ISSR gel using $1.67 \%$ agarose, with 1 X TBE using gel electrophoresis chamber. Eight micro litter ISSR amplification products and $2 \mu \mathrm{l}(6 \mathrm{X})$ loading dye $(0.12 \%$ bromo-phenol blue and $30 \%$ glycerol) were mixed thoroughly and loaded on the gel. A 1200 bp ladder (molecular marker) was used to estimate the molecular size of the DNA fragments. The gel was run on electrophoresis machine for $2 \mathrm{~h}$ at constant voltage of $100 \mathrm{~V}$. The ISSR band patterns were visualized and photographed under UV light using Biometra Biodoc analyzer.

\section{Data scoring and statistical analysis}


ISSR bands were scored as present (1) and absent (0) representing the ISSR profile of each sample. For each ISSR marker, total amplified bands, number of polymorphic bands, and percentage of polymorphic bands (PPB) were determined. The 0/1 matrix data was analyzed using Free Tree 0.9.1.50 [27] and NTSYSpc version 2.02 Rohlf (2000) software to calculate the Jaccard's similarity coefficient for all possible pairs of samples. Jaccard's similarity coefficient was calculated as:

$$
s_{i j}=\frac{a}{a+b+c}
$$

where, $S_{i j}$ is Jaccard's similarity coefficient, a is the total number of bands shared between individuals i and $\mathrm{j}, \mathrm{b}$ is the total number of bands present in individual $\mathrm{i}$ but not in individual $\mathrm{j}$ and $\mathrm{c}$ is the total numbers of bands present in individual $j$ but not in individual $i$. The resulting similarity matrices were employed to construct UPGMA-based dendrogram. The unweighted pair group method with arithmetic mean (UPGMA) was used in order to determine the genetic relationship among accessions using NTSYS- pc version 2.02 [28]. The matrix of genetic similarity was also used in a principal coordinate analysis (PCoA) to resolve the patterns of clustering among the accessions based on Jaccard's coefficient.

Percent of polymorphism, Nie's pairwise gene diversity and Shannon's Weaver pairwise diversity index (I) were determined with POPGENE software 1.32 [29]. The binary data generated were used to determine levels of polymorphism by dividing the polymorphic bands by the total number of scored bands. Genetic diversity measures were tested using Nei's gene diversity statistics. Shannon's diversity index (I) was also used to examine partitioning of genetic diversity within and among populations.

To measure the informativeness of the ISSR markers to differentiate between the A. hypogaea accessions, polymorphism information content (PIC), effective multiplex ratio (EMR), marker Index (MI) and resolving power (RP) were calculated. The value of polymorphism information content (PIC) was calculated using software Power Marker version 3.2 [30]. The PIC was calculated by the formula: $\mathrm{PIC}=2 \mathrm{Pi}(1-\mathrm{Pi})$, where, $\mathrm{Pi}$ is the frequency of occurrence of polymorphic bands in different priers. EMR is the product of the fraction of polymorphic bands and the number of polymorphic bands [31]. MI was determined according to Powell et al. [32] as the product of PIC and EMR. RP was calculated using the formula RP= $\sum \mathrm{lb}$, where $\mathrm{lb}$ is band informativeness and $\mathrm{lb}=1-[2 \times(0.5-p)]$, where $\mathrm{p}$ is the proportion of genotypes containing the band [33].

\section{Results}

\section{ISSR polymorphism}

Four of nine ISSR primers used (Table 3) could produce reproducible bands ranging in size from 120 to $1100 \mathrm{bp}$ (Fig. 2). Fifty-six bands were generated across the four ISSR primers, of which 29 (51.8\%) were polymorphic (Table 3). The amplified bands by the primers range from 12 (UBC841) to 18 (UBC881) across the accessions. The number of polymorphic bands of the primers ranged from 5 in primer UBC841 and 
UBC881 to 11 in primer UBC857. The percentage of polymorphism for primers ranged from $27.8 \%$ in primer UBC881 to $84.6 \%$ in primer UBC 857 , with an average polymorphism percent of $51.8 \%$ (Table 3 ).

Table 3

Percent of polymorphism and polymorphism information content (PIC) generated in A. hypogaea using four ISSR Primers

\begin{tabular}{|c|c|c|c|c|c|c|}
\hline Primer & $\begin{array}{l}\text { Sequence } \\
5^{\prime}-3^{\prime}\end{array}$ & $\begin{array}{l}\text { Annealing } \\
\mathrm{T}\left({ }^{\circ} \mathrm{C}\right)\end{array}$ & $\begin{array}{l}\text { Total } \\
\text { number } \\
\text { of bands }\end{array}$ & $\begin{array}{l}\text { No. of } \\
\text { polymorphic } \\
\text { bands }\end{array}$ & $\begin{array}{l}\% \text { of } \\
\text { polymorphism }\end{array}$ & PIC \\
\hline UBC810 & (GA) $8 \mathrm{~T}$ & 45 & 13 & 8 & $61.5 \%$ & 0.49 \\
\hline UBC841 & $(G A) 8 Y C$ & 48 & 12 & 5 & $41.7 \%$ & 0.42 \\
\hline UBC857 & (AC)8YG & 48 & 13 & 11 & $84.6 \%$ & 0.76 \\
\hline UBC881 & $(\mathrm{GGGGT}) 3 \mathrm{G}$ & 48 & 18 & 5 & $27.8 \%$ & 0.29 \\
\hline Total & & & 56 & 29 & $51.8 \%$ & 0.49 \\
\hline
\end{tabular}

In the present study, the di-nucleotide primers, namely UBC810, UBC841 and UBC857 were observed to have $61.5 \%, 41.7 \%$ and $84.6 \%$ of polymorphism, respectively. The penta-nucleotides primer UBC881 was observed to have $27.8 \%$ polymorphism. A representation of the ISSR band profile obtained with primer UBC857 is shown (Fig. 3). In the present study, the di-nucleotide ISSR primers UBC857 with AC repeats and UBC810 with GA repeats, detected higher polymorphism among accessions compared with pentanucleotide primer.

\section{Polymorphism Information Content (PIC)}

Polymorphism information content (PIC) is the probability of detection of polymorphism by a primer/primer combination between two randomly drawn genotypes and depends on the number of detectable alleles and the distribution of their frequency. In the present study, the PIC value varied from 0.29 (primer UBC881) to 0.76 (primer UBC857) with an average value of 0.49 (Table 3).

\section{Marker Index (MI) and Effective multiplex ratio (EMR)}

The calculated Marker Index (MI) value for all primers ranged between 1.49 (UBC881) and 11.01 (UBC857). The effective multiplex ratio (EMR), the number of polymorphic fragments detected per assay, varied from 5 to 26 with a mean value of 15.94 .

\section{Resolving power (RP)}

The resolving power (RP) is a parameter that specifies the discriminatory potential of the primers (the ability of a primer to generate optimally informative bands). Many studies have indicated RP index as an important feature of a good marker system [34, 35, 36, 37]. In the present study, the estimated RP for primers varied from 2.65 (UBC881) to 18.34 (UBC857) with an average value of 10.46. The highest RP values suggesting the capacity of the primers used to distinguish among different accessions. RP was 
positively correlated with total amplified bands, number of polymorphic bands, MI and EMR at $\mathrm{P}<0.01$. MI and EMR were positively correlated with RP $(r=0.924$ and $r=0.738$, respectively, $P<0.01)$ and also positively correlated with PIC.

\section{Genetic Diversity}

The lowest Nei's gene diversity $(\mathrm{H})$ value was 0.11 between GOG-6 (Gursum/Oda-3) and GOB-10 (Babile/Medigana-1) and the highest was between GOBG-1 (Bale/Ginir) and GOB-14 (Babile/ Tofic-2) at 0.38 , with a mean value of 0.245 . The lowest Shannon's indices (I) value was 0.24 between GOG-6 (Gursum/Oda-3) and GOB-10 (Babile/Medigana-1) and the highest value was 0.41 between GOBG-1 (Bale/Ginir) and GOB-14 (Babile/ Tofic-2) with a mean value of 0.325. The highest genetic distance values belonged to GOBG-1 (Bale/Ginir) and GOB-14 (Babile/Tofic-2) accessions, which were genetically the most distant accessions.

The mean observed number of alleles $(\mathrm{Na})$ ranged from $1.347 \pm 0.433$ in 'GOB-14 (Babile/ Tofic-2)' and 'GOG-6 (Gursum/Oda-3)' accessions to a maximum of 1.574 \pm 0.485 in 'GOBG-1 (Bale/Ginir)' accession. Values of the effective number of alleles $(\mathrm{Ne})$ were less than those for $(\mathrm{Na})$ with regard to every accessions and ranged from $1.163 \pm 0.316$ in 'GOB-14 (Babile/ Tofic-2)' to $1.328 \pm 0.393$ in 'GOBG-1 (Bale/Ginir)'. Total gene diversity $(\mathrm{Ht})$ and gene diversity among accessions $(\mathrm{Hs})$ were $0.3166 \pm 0.042$ and $0.141 \pm 0.065$, respectively. The heterozygosity among the accessions ranged from 0.098 in 'GOB-14 (Babile/ Tofic-2)' to 0.174 in 'GOBG-1 (Bale/Ginir)'. The coefficient of gene differentiation (Gst) among accessions was 0.294. Based on the Gst value, the mean estimated number of gene flow ( $\mathrm{Nm}$ ) between accessions was found to be 0.827 (Table 4).

Table 4

Overall genetic variability across all studied $A$. hypogaea $L$. accessions.

\begin{tabular}{|c|c|c|c|c|c|c|c|c|}
\hline Sample size & $\mathrm{Na} \pm(\mathrm{SD})$ & $\begin{array}{l}\mathrm{Ne} \pm \\
\text { (SD) }\end{array}$ & $\begin{array}{l}\mathrm{H} \pm \\
\text { (SD) }\end{array}$ & $\mathrm{I} \pm(\mathrm{SD})$ & $\mathrm{Ht} \pm(\mathrm{SD})$ & $\mathrm{Hs} \pm$ (SD) & Gst & $\mathrm{Nm}$ \\
\hline \multirow[t]{3}{*}{43} & 1.461 & 1.245 & 0.245 & 0.325 & 0.3166 & 0.141 & 0.294 & 0.827 \\
\hline & \pm & \pm & \pm & \pm & \pm & \pm & & \\
\hline & 0.459 & 0.355 & 0.095 & 0.164 & 0.042 & 0.065 & & \\
\hline
\end{tabular}

For primers, the highest observed number of alleles $(1.980 \pm 0.640)$ and effective number of alleles $(1.85 \pm$ 0.12 ) were recorded by primer UBC857 and the least observed number of alleles $(1.600 \pm 0.520)$ and effective number of alleles $(1.42 \pm 0.41)$ was shown by primer UBC841. The highest gene diversity $(0.46 \pm$ $0.036)$ and Shannon index $(0.657 \pm 0.037)$ was shown by primer UBC857 and followed by primer UBC810, with gene diversity and Shannon index value of $(0.46 \pm 0.036$ and $0.413 \pm 0.322)$, respectively (Table 5$)$ and 
the least value of genetic diversity and Shannon index was recorded in primer UBC841 with $0.25 \pm 0.22$ and $(0.364 \pm 0.326)$ value respectively.

\section{Table 5}

Overall genetic variability across used ISSR primers

\begin{tabular}{|lllll|}
\hline Primer & $\mathrm{Na} \pm(\mathrm{SD})$ & $\mathrm{Ne} \pm(\mathrm{SD})$ & $\mathrm{H} \pm(\mathrm{SD})$ & $\mathrm{I} \pm(\mathrm{SD})$ \\
\hline UBC810 & $1.643 \pm 0.500$ & $1.54 \pm 0.42$ & $0.31 \pm 0.23$ & $0.413 \pm 0.322$ \\
\hline UBC841 & $1.600 \pm 0.520$ & $1.42 \pm 0.41$ & $0.25 \pm 0.22$ & $0.364 \pm 0.326$ \\
\hline UBC857 & $1.980 \pm 0.640$ & $1.85 \pm 0.12$ & $0.46 \pm 0.036$ & $0.657 \pm 0.037$ \\
UBC881 & $1.680 \pm 0.480$ & $1.52 \pm 0.39$ & $0.29 \pm 0.21$ & $0.419 \pm 0.291$ \\
\hline Average & $1.726 \pm 0.535$ & $1.58 \pm 0.32$ & $0.32 \pm 0.17$ & $0.463 \pm 0.244$ \\
\hline $\begin{array}{l}\text { Na = Observed number of alleles. Ne = Effective number of alleles. } \mathrm{H}=\text { Nei's gene diversity. I = Shannon's } \\
\text { Information index. }\end{array}$
\end{tabular}

\section{Genetic Relationship}

The generated similarity matrix by ISSR based on the Jaccard's pairwise similarity coefficient matrices showed similarity ranged from $44 \%$ to $83 \%$. The average similarity across the 43 accessions was found to be $63.5 \%$. The lowest genetic similarity value (i.e. maximum diversity) was found between accessions GOBG-1 (Bale/Ginir) and GOB-14 (Babile/Tofic-2) (44\%) followed by that between GOG-1 (Gursum/Llalemi1) with GAW-1 (Amhara/Wangua) and GOB-17 (Babile/Gemechu) with GOBG-1 (Bale/Ginir) at a similarity value of $46 \%$. The highest similarity coefficient (i.e. minimum diversity) was found between the accessions GOG-6 (Gursum/Oda-3) with GOB-10 (Babile/Medigana-1) and GOB-7 (Babile/Ifa-gendi-1) with GOB-16 (Babile /Gende) 83\% followed by that between GOG-12 (Gursum/Odaa-2) with GOB-9 (Babile/Ifa-gendi-3) at a similarity value of $82 \%$.

\section{Cluster Analysis}

UPGMA clustering analysis put the accessions into one cluster at $59.2 \%$ similarity. However, the accessions were clustered in to five clusters based on the cut-off point of $63.5 \%$ similarity (Fig. 4). The dendrogram for the accessions (Fig. 4) did not divide the accessions into distinct groups resembling their geographical origin. The UPGMA analysis revealed that individuals in each accession were distributed and inter-mixed with individuals of another locality. No specific/significant trend of grouping of accessions was observed. For instance, the accessions from Gursum and/or Babile were distributed in all 5 distinct clusters. Moreover, accessions from distant geographical locations were clustered together with other accessions from different regions. This fact becomes evident, for example, at the top of the cluster 'GOBG-1' accession from Bale/Ginir was clustered with accessions from Babile and Gursum. Similarly, at the bottom and middle of the clusters the accessions from GAW-1 (Amhara/wangua) and GSJ-1 (Somalia/Jigjiga/Beledka) were clustered with accessions from Babile and Gursum.

Moreover, a loose clustering of accessions as per their geographical proximity was observed. For example, accessions from Babile (62.5\%) and Gursum (61.5\%) were grouped in cluster I sub cluster I and II, 
respectively (Fig. 4).

\section{Principal Coordinate Analysis (PCOA)}

All the data obtained using four ISSR primers were used for PCoA using Jaccard's coefficients of similarity. The first two components of the coordinates of the PCoA having eigen values of 16.3 and 8.2 with variance of $33.2 \%$ and $16.4 \%$, respectively, and together $49.6 \%$ used to show the grouping of individuals using two co-ordinates. Similar to the UPGMA clustering pattern, the 43 accessions of $A$. hypogaea were grouped into five groups (clusters) based on the principal co-ordinate analysis (Fig. 5).

The PCoA plot indicated that most of the accessions did not group together with other accessions originated from the same geographical location (Fig. 5). This result is in line with the result obtained in UPGMA. However, most of the accessions that show geographical proximity were found to form distinct groups and spread all over the plot (Fig. 5). In addition, accessions from distant geographical locations tend to form similar group or cluster. As the result, low coefficient of variation was observed in A. hypogaea accessions considered in this study.

\section{Discussion}

In the present study ISSR profile was used for diversity analysis and relationship among different $A$. hypogaea accessions. Several studies on populations indicate the percentage of the polymorphic locus as an important measure of genetic diversity [14]. A. hypogaea showed moderate genetic diversity as indicated by percent polymorphic loci $(p=51.8 \%)$. A study reported $54 \%$ of polymorphism among 13 A. hypogaea accessions using ISSR markers [15]. The observed highest Nei's gene diversity $(H)$ value $(0.38 \pm 0.174)$, and the highest Shannon's indices $(0.41 \pm 0.194)$ shows presence of genetic diversity among the studied accessions. The Shannon index vary from 0 to 1 , and lower genetic diversity is represented by values closer to zero [39].

In the present study, the PIC value varied from 0.29 (primer UBC881), less informative to 0.76 (primer UBC857), high informative with an average value of 0.49 . PIC value of 0.70 and above is highly informative whiles a value of $\sim 0.44$ is moderately informative. PIC is a statistic that measures the usefulness of a genetic marker for linkage analysis [38].

The genetic differentiation of a species reflects the interactions of various evolutionary processes including long-term evolutionary history, such as shifts in distribution, habitat fragmentation and population isolation, mutation, genetic drift, mating system, gene flow and natural selection [42]. The coefficient of gene differentiation (Gst) for the entire accessions of $A$. hypogea was 0.29 , suggesting a restricted genetic differentiation between accessions. The average value of differentiation might reflect the interactions of various factors including reduced geographic range in most of the accessions, inter and intra-regional climates, their breeding system and limited genetic drift or genetic isolation of the samples.

Based on the Gst value, the mean estimated number of gene flow $(\mathrm{Nm})$ for the entire accessions was found to be 0.827 (Table 4). In flowering plant, the level of $\mathrm{Nm}$ is divided into three grades: high, $\mathrm{Nm}$ equal to or 
larger than 1.0; moderate, $\mathrm{Nm}$ ranging from 0.250 to 0.99 ; and low, $\mathrm{Nm}$ ranging from 0.00 to 0.249 [43]. Gene flow is generally considered as the main factor that could homogenize the genetic structure of populations in their distribution area. According to Wright (1931) [44], $\mathrm{Nm}^{1} 1 / 41$ is sufficient to overcome the effects of genetic drift. Also, species with low gene flow have higher genetic differentiation than species with high gene flow. However, our results indicated that virtually moderate gene flow occurred between the accessions of $A$. hypogaea.

Based on Jaccard's similarity coefficient, highest genetic similarity observed among accessions suggests that the existence of genetic similarity among the accessions possibly due to gene flow. On the other hand, the least genetic similarity observed between some accessions is useful in broadening genetic base of $A$. hypogaea accessions in Ethiopia and these accessions should be considered as the primary/valuable sites in conservation and breeding program of the crop. Both PCoA and UPGMA cluster analysis shows the clustering of all 43 accessions into five clusters without clear geographical differentiation. This might be due to gene flow caused by the exchange of seeds by farmers in Ethiopia.

Knowledge on the genetic diversity of the selected individuals is of ultimate importance, since it contributes to the information on the species and allows the selection of genotypes to be included in future conservation programs. Thus, the most divergent genotypes can be selected to maintenance the level of genetic diversity of a species to keep its ability to adapt to novel environmental changes. The present finding also contributes valuable information on the genetic diversity of $A$. hypogaea accessions grown in Ethiopia.

Parameters such as MI and EMR have been used for assessing the informative potential of molecular markers in various genetic diversity studies [31,34]. In the present study, the primers that generated high number of bands had higher MI and EMR values. MI and EMR were positively correlated with RP $(r=0.924$ and $r=0.738$, respectively, $P<0.01)$ and PIC. The resolving power $(R P)$ is a parameter that specifies the discriminatory potential of the primers (the ability of a primer to generate optimally informative bands). Many studies have indicated RP index as an important feature of a good marker system [34, 35, 36, 37]. In the present study, the highest RP value 18.34 (UBC-857) suggesting the capacity of the primer used to distinguish among different accessions. RP was positively correlated with total amplified bands, number of polymorphic bands, $\mathrm{MI}$ and EMR at $\mathrm{P}<0.01$, suggesting the informativines of the ISSR primers used in the present study.

ISSR markers have demonstrated their efficiency in the study of genetic variability for several other species. Many studies have proved the effectiveness of this marker in articles on genetic diversity and characterization of accessions between and within populations, such as those with, Capparis spinosa L. [45], Pitcairnia flammea [46] Erythrina velutina [47] and Croton tetradenius [48].

\section{Conclusions}

The study has revealed genetic polymorphism (51.8\%) among the $A$. hypogaea accessions. The highest genetic similarity observed among the accessions of $A$. hypogaea and the observed five clusters without 
clear geographical differentiation suggest the existence of genetic similarity among the accessions possibly due to gene flow caused by seed exchange. The ISSR based fingerprinting of $A$. hypogaea accessions demonstrated the usefulness of the marker in estimating the extent of genetic variation and genetic relationships among $A$. hypogaea accessions. To conclude, the present finding is an important milestone for future germplasm collection, sound conservation, improvement and breeding of the crop. Further study with more geographic range and the use of additional molecular markers would give additional picture of the genetic diversity of $A$. hypogaea accessions in Ethiopia.

\section{Abbreviations}

EBI: Ethiopian biodiversity institute; ISSR: Inter simple sequence repeats; PCoA: Principal coordinate analysis; PCR: Polymerase Chain Reaction; PIC: Polymorphism information content; UPGMA: Unweighted pair group method with arithmetic mean

\section{Declarations}

\section{Acknowledgements}

Ethiopian Biodiversity Institute and Plant Molecular Genetics Research Laboratory of Addis Ababa University are duly acknowledged for providing germplasm and laboratory facility for DNA analysis respectively.

\section{Authors' contributions}

MA designed and preformed the experiment, analyzed data, prepared the draft manuscript; MK designed the experiment, supervised the research, revised the manuscript and correspondence of the paper; and TF designed the experiment, supervised the research and revised the manuscript. All authors read and approved the final manuscript.

\section{Funding}

This work was financially supported by Adama Science and Technology University

\section{Availability of data and materials}

The datasets used and/or analyzed during the current study are available from the authors

\section{Ethics approval and consent to participate}

Not applicable 


\section{Consent for publication}

Not applicable

\section{Competing interests}

The authors declare that they have no competing interests

\section{Author Details}

${ }^{1}$ Department of Applied Biology, School of Applied Natural Sciences, Adama Science and Technology University, P.O.Box 1888, Adama, Ethiopia; ${ }^{2}$ Department of Biotechnology, College of Natural and Computational Science, Axum University, P.O.Box 1010, Aksum, Ethiopia; ${ }^{3}$ Institute of Biotechnology, College of Natural Science, P.O.Box 1176, Addis Ababa University, Addis Ababa, Ethiopia; E-mail

\section{References}

1. Stalker HT. Peanut (Arachis hypogaea L.). Field Crops Research. 1997;53:205-17.

2. Mastewal A, Sakhuja PK, Mashila D. Evaluation of released and local groundnut rust (Puccinia arachis) at Babile Eastern Ethiopia. Open Access Journal of Agricultural Research. 2017;2(1):1-8.

3. Taru VB, Kyagya IZ, Mshelia SI. Profitability of groundnut production in Michika local government area of Adamawa State, Nigeria. J Agric Sci. 2010;1(1):25-9.

4. Hamakareem HF, Hamahasan BM, Ali SHS. Influence of plant spacing on the growth and yield of groundnut (Arachis hypogaea L.). International Journal of Current Research in Bioscience Plant Biology. 2016;3(10):7-12.

5. Kathirvelan K, Kalaiselvan P. Studies on agro-management techniques for confectionary groundnut under irrigated condition. Research Journal of Agricultural Biological Science. 2007;3:52-8.

6. Jiaramraja PR, Fantahun W. Characterization of yield components in certain groundnut (Arachis hypogaea L.) varieties of Ethiopia. Journal of Experimental Biology Agricultural Science. 2014;2(6):593-6.

7. Fredu N, Kai M, Rao KPC, Gizachew L. Scoping study on current situation and future market outlook of groundnut in Ethiopia. ICRISAT, Socioeconomics Discussion Paper Series Number 38, Nairobi, Kenya; 2015.

8. Addisu G, Ermias T. Value chain assessment study of groundnut (Arachis hypogaea L.) in Northwestern Ethiopia. British Journal of Economic Management Trade. 2017;16(2):1-15.

9. Gebreselassie R, Dereje A, Solomon H. On farm pre harvest agronomic management practices of Aspergillus infection on groundnut in Abergelle, Tigray. Journal of Plant Pathology Microbiology. 2014;5(2):1-6. 
10. Johan PM, Bello LL, Lucky O, Midau A, Moruppa SM. Review. The importance of molecular markers in plant breeding programs. Global Journal of Science Frontier Research. 2011;11(5):4-12.

11. Bhandari HR, Bhanu AN, Srivastava K, Singh MN, Shreya A. Assessment of genetic diversity in crop plants - an overview. Advanced in Plants Agriculture Research. 2017;7(3):00255.

12. Linda M, Arshiya N, Mario AP. Assessing plant genetic diversity by molecular tools. Diversity. 2009;1:19-35.

13. Duzyaman E. Phenotypic diversity within a collection of distinct okra (Abelmoschus esculentus) cultivars derived from Turkish landraces. Genetics Research Crop Evolution. 2005;52:1019-30.

14. Soares ANR, Vitória MF, Nascimento ALS, Ledo AS. Genetic diversity in natural populations of mangaba in Sergipe, the largest producer State in Brazil. Genetics and Molecular Research. 2016; 15(3): gmr. 15038624.

15. Raina SN, Rani V, Kojima T, Ogihara Y, Singh KP, Devarumath RM. RAPD and ISSR fingerprints as useful genetic markers for analysis of genetic diversity, varietal identification, and phylogenetic relationships in peanut (Arachis hypogaea) cultivars and wild species. Genome. 2001;44(5):763-72.

16. Patel SV, Galakiya BA. Characterization of groundnut (Arachis hypogaea L.) through biochemical markers. International Journal of Tropical Agriculture. 2014;32:815-9.

17. Roomi S, Bibi S, Arshad I, Muhammad S, Izhar M, Muhammad AZ, Muhammad ZA, Farooq R, Abdul G, Nabila T. Genetic diversity analysis in a diverse germplasm of groundnut (Arachis hypogaea L.) from Pakistan. Australia Journal of Crop Science. 2014;8(1):55-61.

18. Peng Z, Gallo M, Barry LT, Diane R, Jianping W. Molecular marker development from transcript sequences and germplasm evaluation for cultivated peanut (Arachis hypogae L.). Molecular Genetics Genomics. 2016;291:363-81.

19. Dhwani S, Arunabh J, Devendra J. Comparative analysis of genetic diversity among 24 groundnut genotype using randomly amplified polymorphic DNA and inter simple sequence repeat marker. International Journal of Agricultural Science Research (IJASR). 2017;7(3):133-48.

20. Yusuf Z, Zeleke H, Mohammed W, Hussein S, Hugo A. Genetic divergence and association of traits among groundnut (Arachis hypogaea L.) genotypes in Ethiopia based on agro-morphological markers. American Journal of Plant Biology. 2017;2:1-5.

21. Zhang LH, Byrne DH, Ballard RE, Rajapakse S. Microsatellite marker development in rose and its application in tetraploid mapping. Journal of American Society of Horticultural Science. 2006;131(3):380-87.

22. Golkar P, Arzani A, Rezaei AM. Genetic variation in Saffler (Carthamus tinctorious L.) for seed qualityrelated traits and inter simple sequence repeat (ISSR) markers. Int J Mol Sci. 2011;12(4):2664-77.

23. Zeitkiewicz E, Rafalski A, Labuda D. Genome fingerprinting by simple sequence repeat (SSR) anchored polymerase chain reaction amplification. Genomics. 1994;20:176-83.

24. Mishra KK, Fougat RS, Ballani A, Thakur V, Jha Y, Bora M. Potential and application of molecular markers techniques for plant genome analysis. International Journal of Pure Applied Bioscience. 2014;2(1):169-88. 
25. Tadele S, Mekbib F, Tesfaye K. Genetic diversity of coffee (Coffea arabica L.) landraces from Southern Ethiopia as revealed by inter simple sequence repeat marker. Global Advanced Research Journal of Agricultural Science. 2014;3(1):024-34.

26. Wang Z, Weber JL, Zhong G, Tanksley SD. Survey of plant short tandem DNA repeats. Theoretical Applied Genetics. 1994;88:1-6.

27. Pavlicek A, Hrda S, Flegr JFT. Freeware program for construction of phylogenetic trees based on distance data and bootstrap/jackknife analysis of the tree robustness. Application in the RAPD analysis of Genus Frenkelia. Folia Biol. 1999;45(3):97-9.

28. Rohlf FJ. NTSYS-pc numerical taxonomy and multivariate analysis system Version 1.8. New York: Exeter Publications Setauket; 2000.

29. Yeh FC, Yang RC, Boyle TJ, Ye ZH, Mao JX. POPGENE 1.32. The user-friendly shareware for population genetic analysis. Edmonton: Molecular Biology and Biotechnology Centre, University of Alberta; 1997.

30. Liu K, Muse SV. Power Marker: Integrated analysis environment for genetic marker analysis. Bioinformatics. 2005;21(9):2128-29.

31. Najaphy A, Ashrafi Parchin R, Farshadfar E. Evaluation of genetic diversity in wheat cultivars and breeding lines using inter simple sequence repeat markers. Biotechnol Biotechnol Equip. 2011;25:2634-8.

32. Powell W, Morgante M, Andree C, Hanagfey M, Vogel J, Tingley S, Rafalski A. A comparison of RFLP, RAPD, AFLP and SSR markers for germplasm. Mol Breeding. 1996;2:225-38.

33. Altıntas S, Toklu F, Kafkas S, Kilian B, Brandolini A, Ozkan H. Estimating genetic diversity in durum and bread wheat cultivars from Turkey using AFLP and SAMPL markers. Plant Breeding. 2008;127(1):9-14.

34. Mondal S, Sutar SR, Badigannavar AM. Comparison of RAPD and ISSR marker profiles of cultivated peanut genotypes susceptible or resistant to foliar disease. Journal of Food Agriculture Environmen. 2008;6(2):181-7.

35. Kayis SA, Hakki EE, Pinarkara E. Comparison of effectiveness of ISSR and RAPD markers in genetic characterization of seized marijuana (Cannabis sativa L.) in Turkey. Afr J Agric Res. 2010;5(21):292533.

36. Sadeghi A, Cheghamirza K. Efficiency of RAPD and ISSR marker systems for studying genetic diversity in common bean (Phaseolus vulgaris L.) cultivars. Annals of Biological Research. 2012;3(7):3267-73.

37. Grativol C, Lira-Medeiros CF, Hemerly AS, Ferreira PCG. High efficiency and reliability of inter-simple sequence repeats (ISSR) markers for evaluation of genetic diversity in Brazilian cultivated Jatrpha curcas L. accessions. Mol Biol Rep. 2011;38(7):4245-51.

38. Hildebrand CE, Torney DC, Wagner RP. Informativeness of Polymorphic DNA Markers. Los Alamos Science. 1992;20:100-2.

39. Silva AVC, Muniz EN, Almeida CS, Vitória MF. Genetic diversity and sex identification in Genipa americana L. Tropical Subtropical Agro ecosystem. 2015;18:81-6.

40. Nei M. Molecular evolutionary genetics. New York: Columbia University Press; 1987. 
41. Silva AVC, Rabbani ARC, Sena-Filho JG, Almeida CS. Genetic diversity analysis of Mangaba (Hancornia speciosa Gomes), an exotic Brazilian tropical species. Tropical Subtropical Agro ecosystem. 2012;15:217-25.

42. Schall BA, Hayworth DA, Olsen KM, Rauscher JT, Smith WA. Phylogeographic studies in plants: problems and prospects. Mol Ecol. 1998;7(4):465-74.

43. Slatkin M. Gene flow and the geographic structure of natural populations. Science. 1987;236(4803):787-92.

44. Wright S. Evolution in Mendelian populations. Genetics. 1931;16(2):97-159.

45. Liu C, Xue GP, Cheng B, Wang X, He J, Liu GH, Yang WJ. Genetic diversity analysis of Capparis spinosa L. populations by using ISSR markers. Genet Mol Res. 2015;14(4):16476-83.

46. Souza-Sobreira FB, Souza GB, Rosado CCG, Miranda FD, Soares TCB, Gontijo ABPL. Genetic diversity in three natural populations of Pitcairnia flammea (L.) John (Bromeliaceae) estimated by ISSR markers. Genet Mol Res. 2015;14(4):15892-901.

47. Souza EMS, Pereira GS, Silva-Mann R, Álvares-Carvalho SV, Ferreira RA. A comparative framework of the Erythrina velutina tree species in reforested land and native populations. Genet Mol Res. 2016;15(2):gmr.15028534.

48. Almeida-Pereira CS, Silva AVC, Alves RP, Feitosa-Alcantara RB, Arrigoni-Blank MF, Alvares-Carvalho SV, Costa TS, White LAS, Pinto VS, Sampaio TS, Blanket AF. Genetic diversity of native populations of Croton tetradenius Baill. using ISSR markers. Genet Mol Res. 2017;16(2):gmr16029602.

\section{Figures}




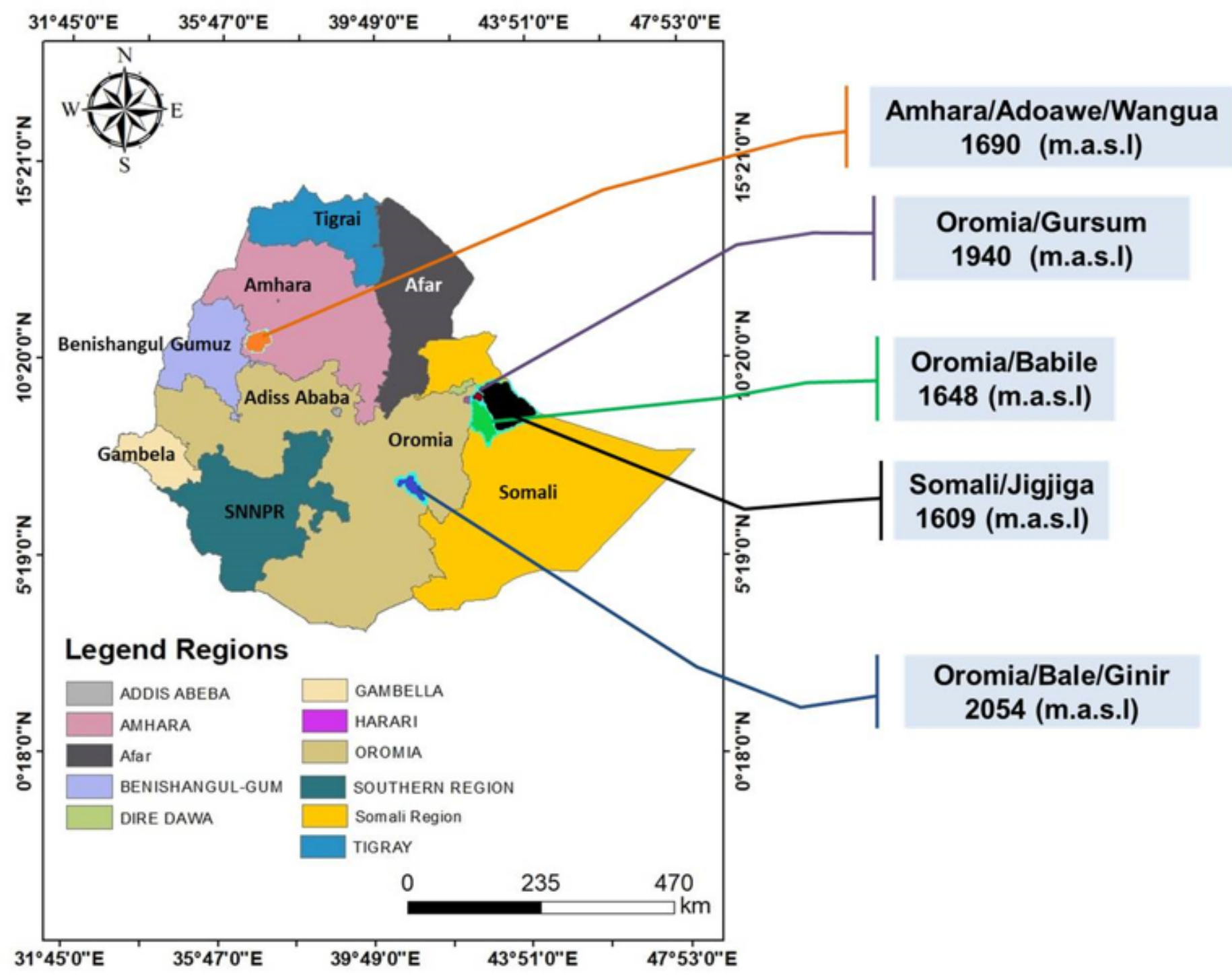

Figure 1

Map of Ethiopia showing collection sites of A. hypogaea accessions 


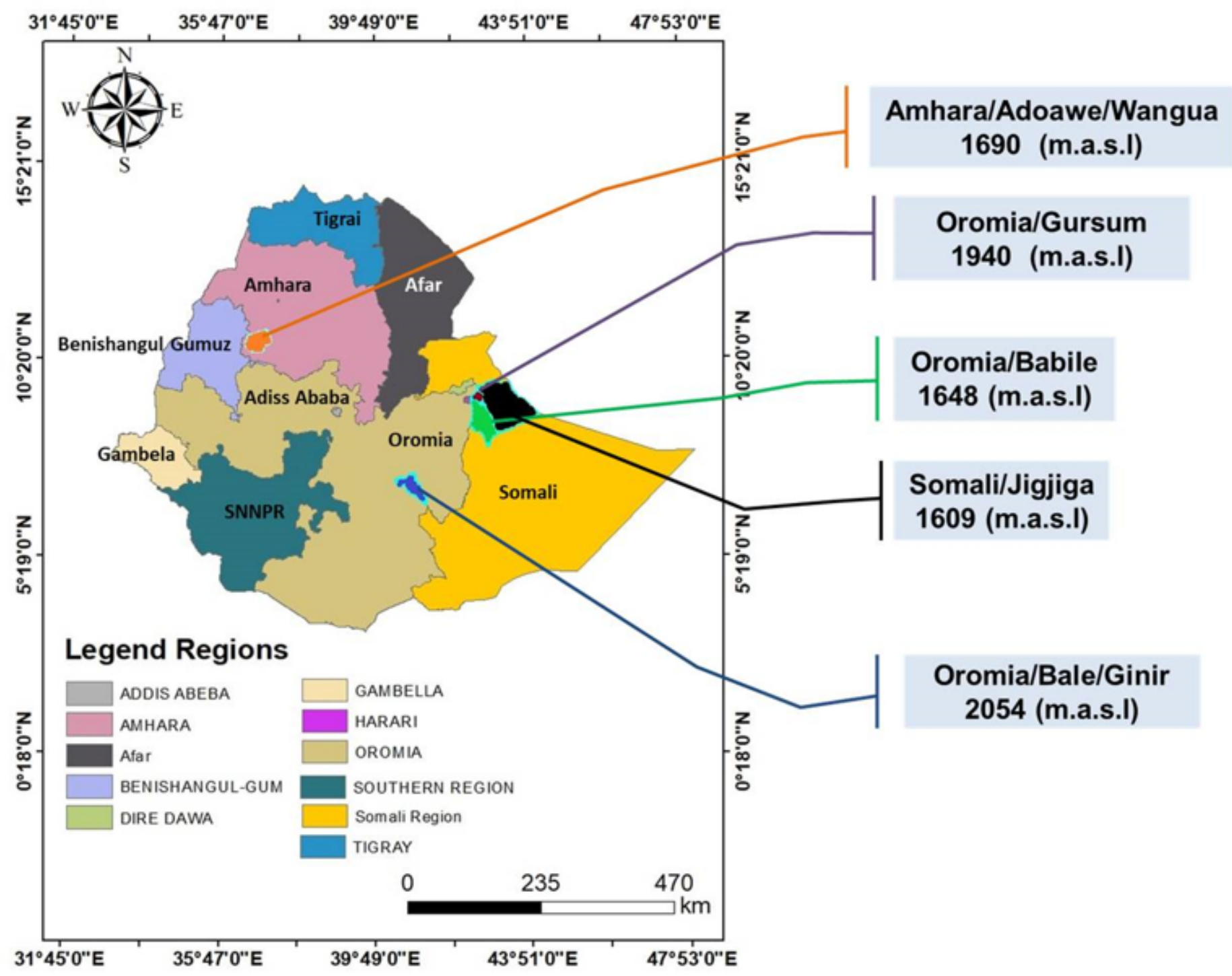

Figure 1

Map of Ethiopia showing collection sites of A. hypogaea accessions 


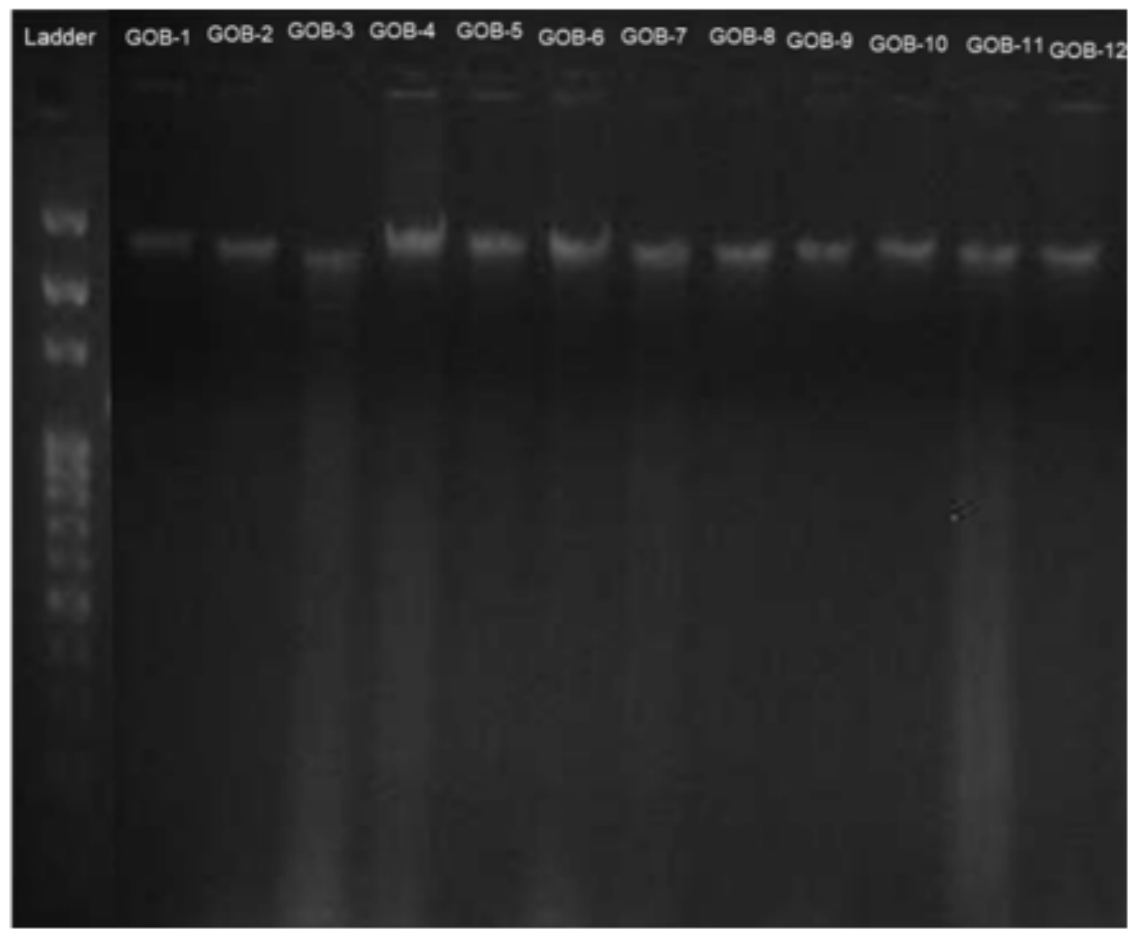

Figure 2

Quality of the DNA in 1\% (w/v) agarose gels in 0.5\% TBE buffer

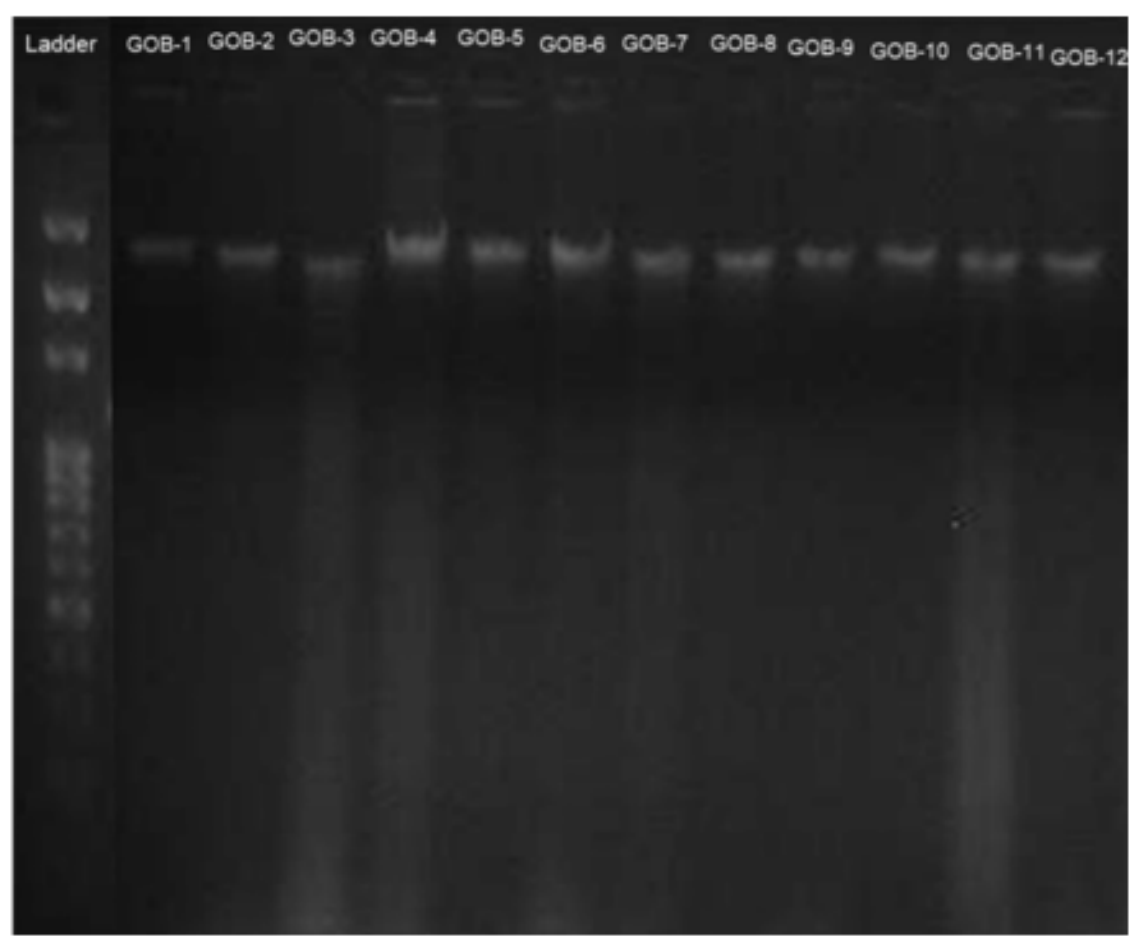

Figure 2

Quality of the DNA in 1\% (w/v) agarose gels in 0.5\% TBE buffer 


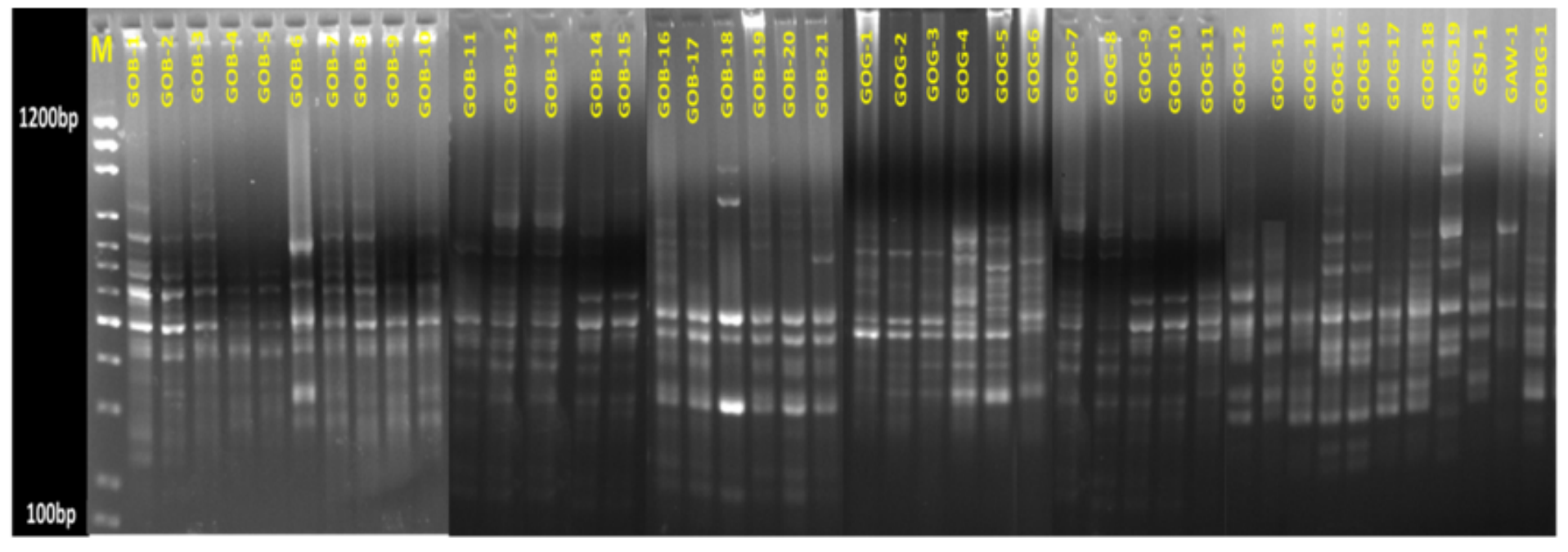

\section{Figure 3}

ISSR banding patterns generated from 43 accessions of A. hypogaea using primers UBC857

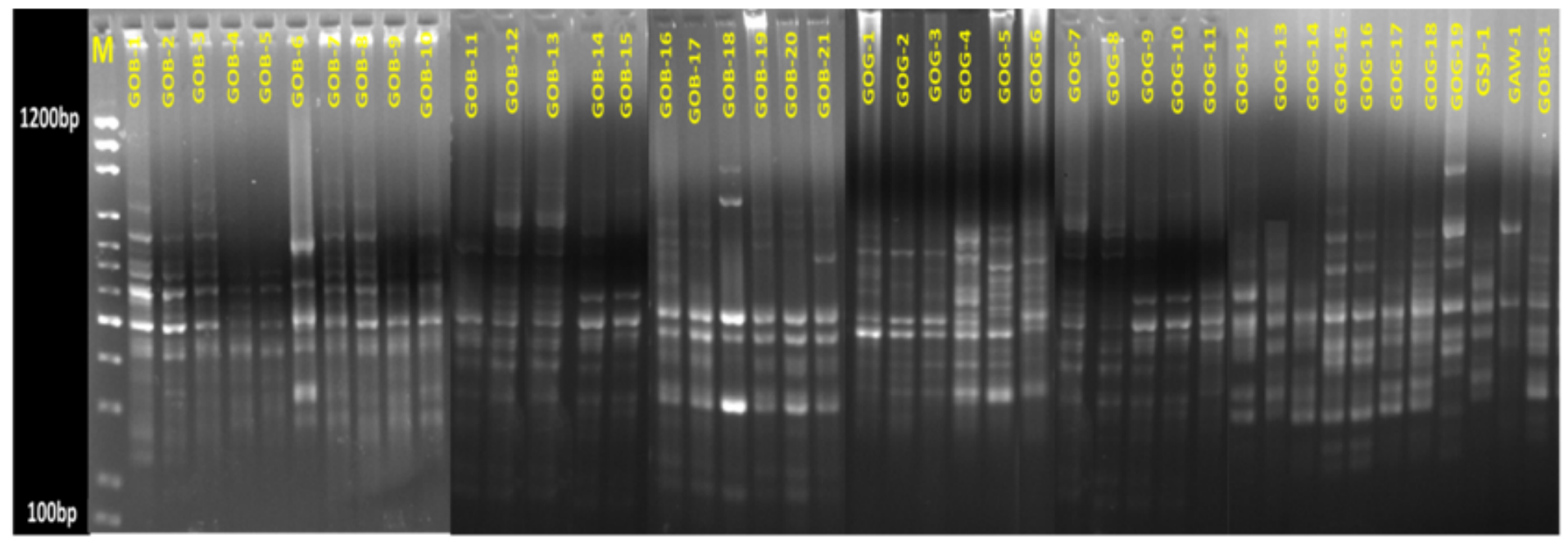

\section{Figure 3}

ISSR banding patterns generated from 43 accessions of A. hypogaea using primers UBC857 


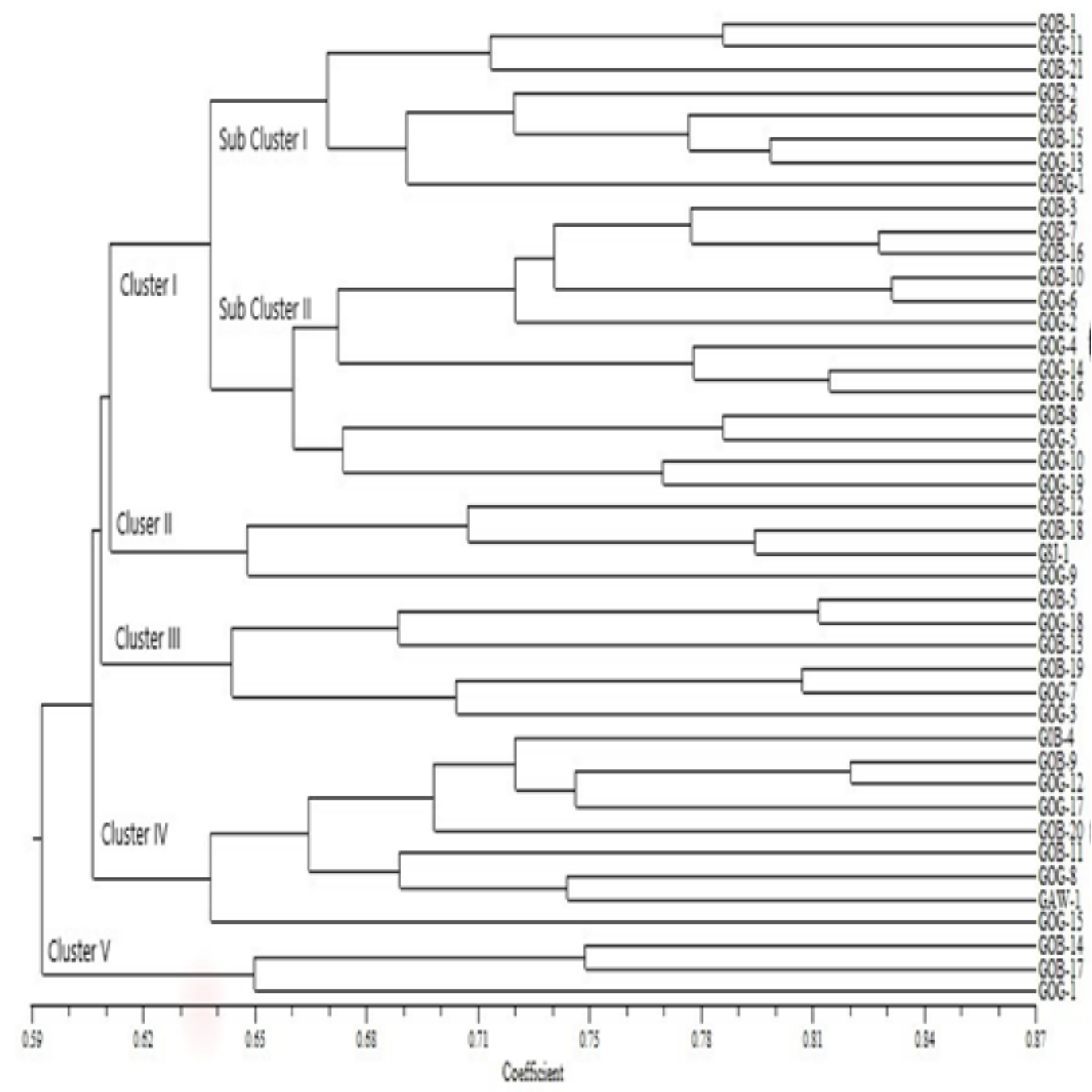

Figure 4

UPGMA cluster analysis of 43 accessions of A. hypogaea Key: GOG - Oromia/Gursum, GOB Oromia/Babile, GOBG - Bale/Ginir, GSJ - Somalia/Jigjiga, GAW - Amhara/Wangua 


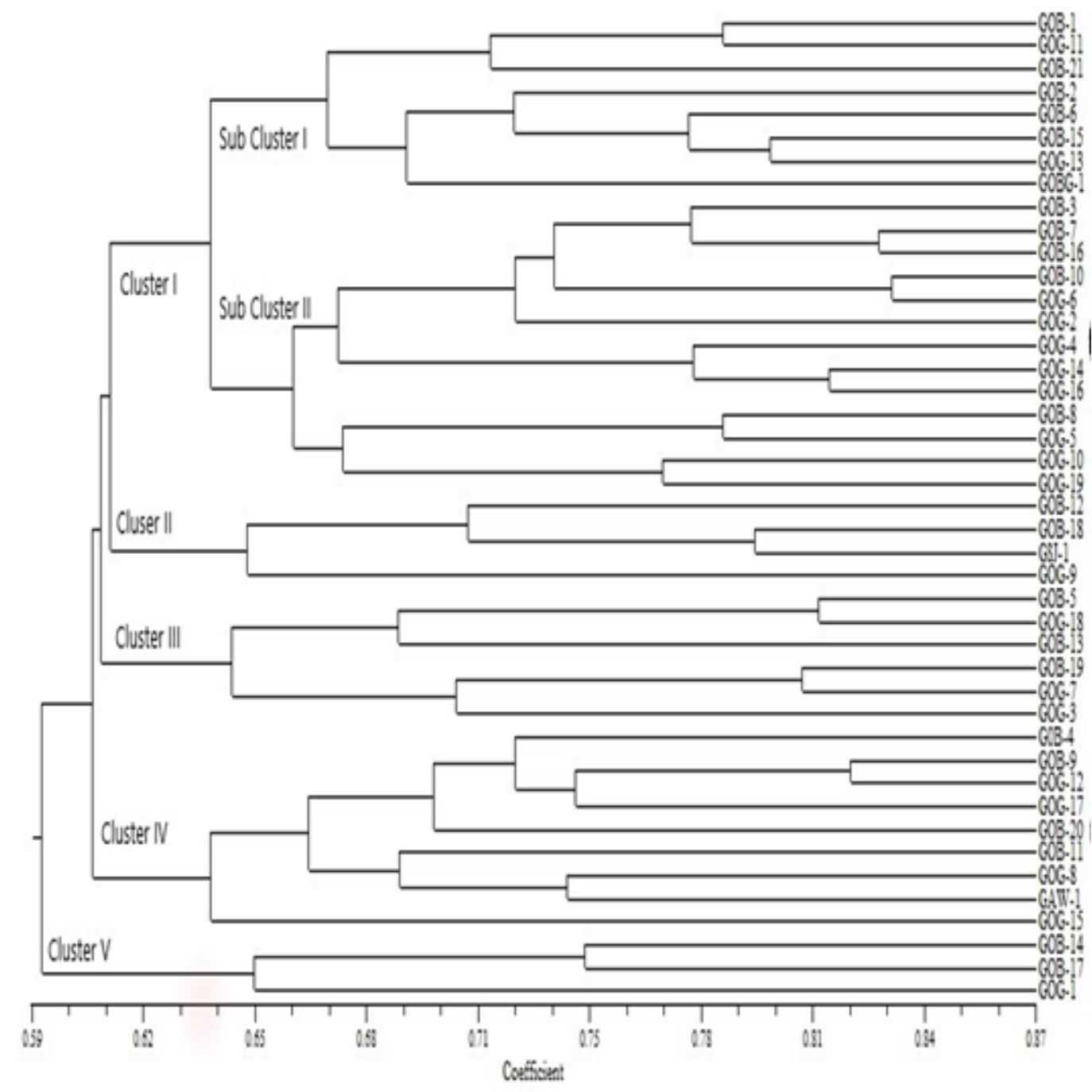

Figure 4

UPGMA cluster analysis of 43 accessions of A. hypogaea Key: GOG - Oromia/Gursum, GOB Oromia/Babile, GOBG - Bale/Ginir, GSJ - Somalia/Jigjiga, GAW - Amhara/Wangua 


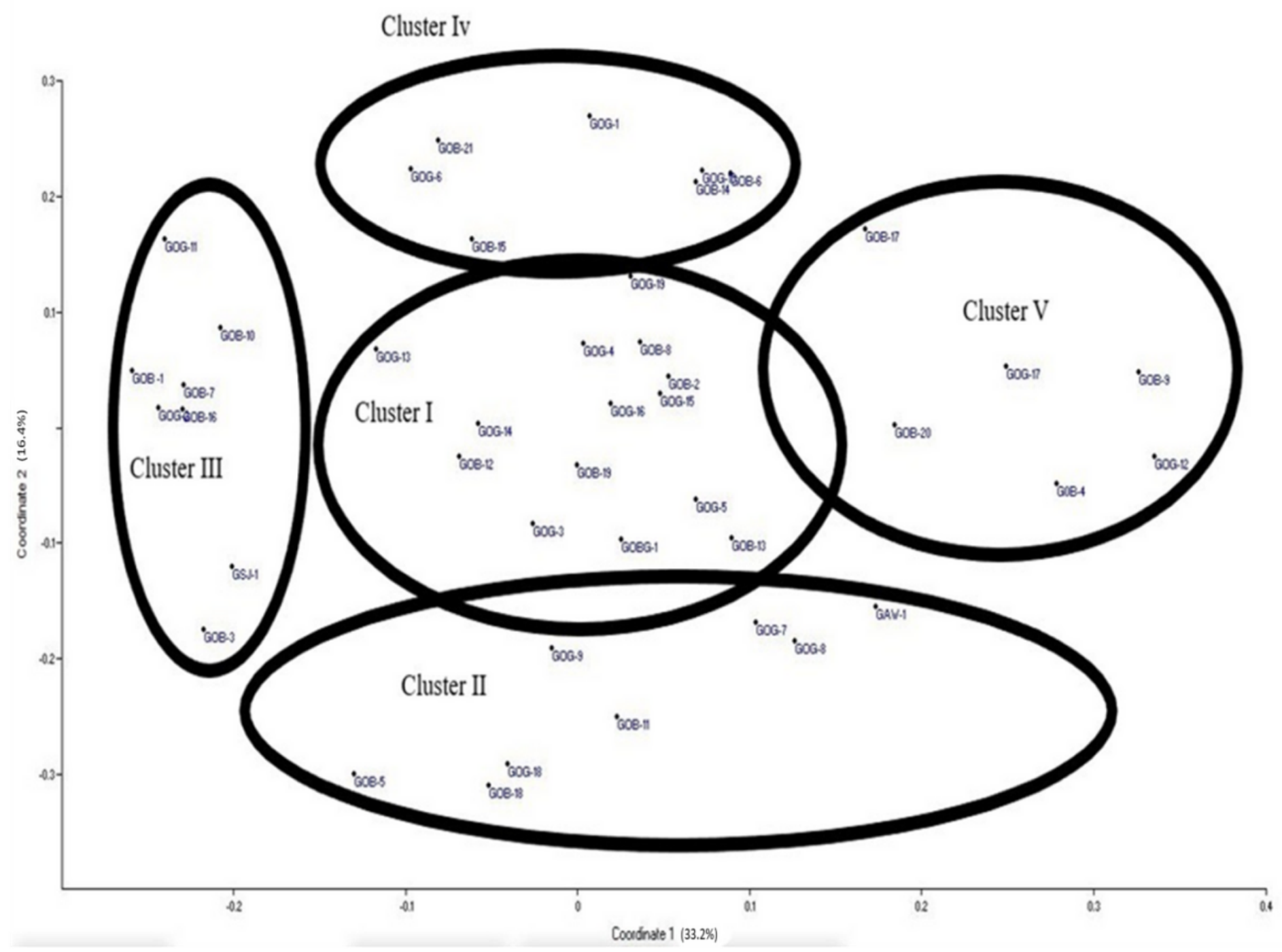

Figure 5

PCoA scatter plot diagram showing genetic relationships of A. hypogaea accessions 


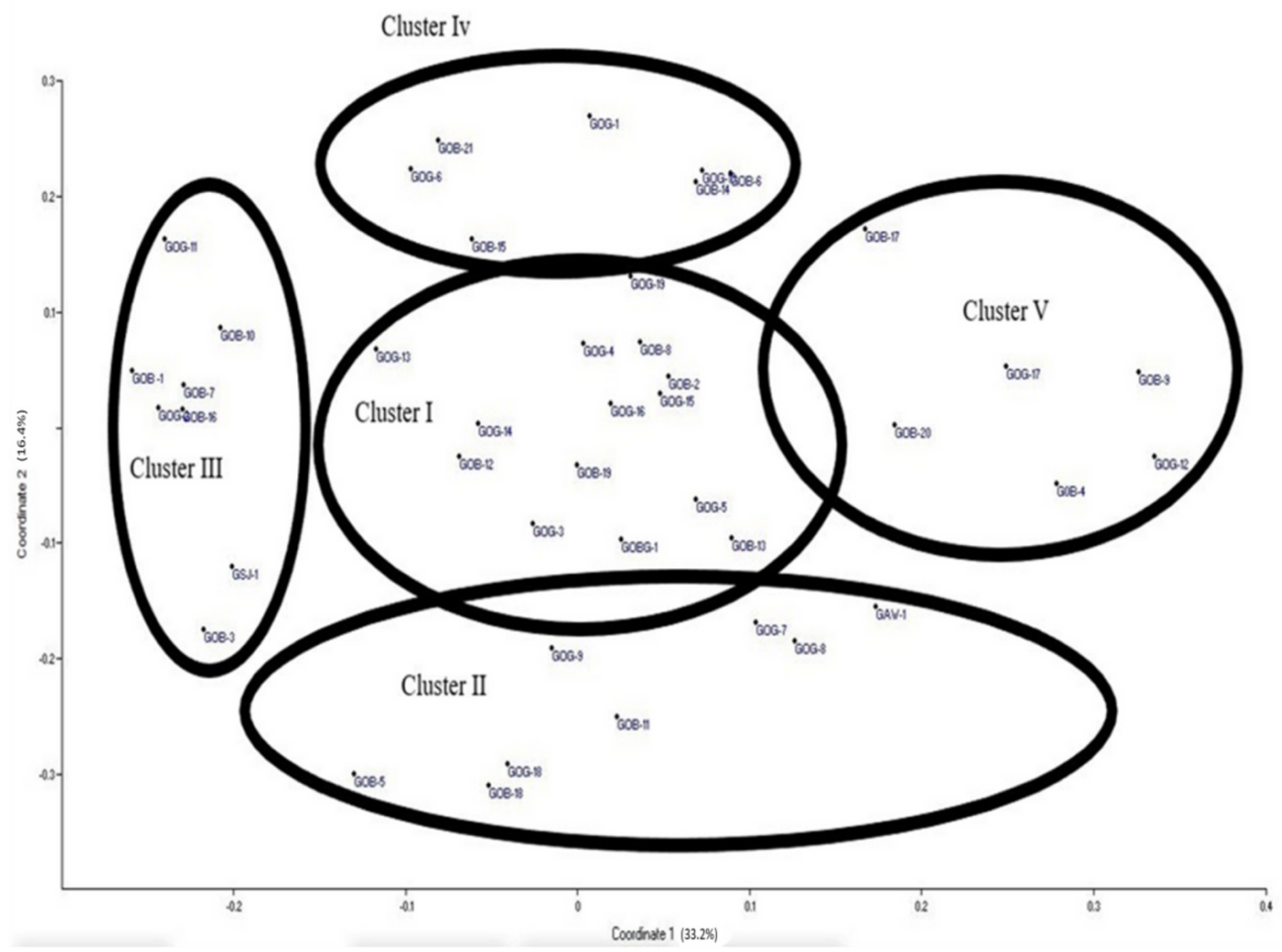

Figure 5

PCoA scatter plot diagram showing genetic relationships of A. hypogaea accessions 